\title{
Evolutionary Aesthetics: Rethinking the Role of Function in Art and Design
}

Dr Graham Coulter-Smith

VisuoSonic research project Southampton Solent University

http://www.visuosonic.org/

g.coulter-smith@staffs.ac.uk

In the first half of the twentieth century there was a remarkable convergence of art and design in De Stijl, Constructivism and the Bauhaus. Via such movements art was able to develop beyond the l'art pour l'art aestheticism of nineteenth century romanticism and postromanticism and enter into the praxis of life. But in the second half of the twentieth century fine art relinquished its liaison with architecture and design.

We find an explanation for this development in Peter Bürger's Theory of the Avant-Garde ${ }^{1}$ which informs us that Dada and Surrealism also pursued a reconciliation of art with everyday life but according to an entirely different philosophy. Bürger's analysis is valuable because he is one of the first theorists to indicate that Dada and Surrealism laid the foundation for postmodern fine art in the second half of the twentieth century. Accordingly his analysis can assist in understanding why postmodern fine art turned away from design and architecture. The following passage from Bürger's analysis, in particular, provides considerable insight:

It is no accident that both Tzara's instructions for the making of a Dadaist poem and Breton's for the writing of automatic texts have the character of recipes. This represents not only a polemical attack on the individual creativity of the artist; the recipe is to be taken quite literally as suggesting a possible activity on the part of the recipient. The automatic texts also should be read as guides to individual production. But such production is not to be understood as artistic production, but as part of a liberating life praxis. This is what is meant by Breton's demand that poetry be practiced (pratiquer la poesie). ${ }^{2}$

Bürger argues that the methodologies developed by Dada and Surrealism entail interactivity. But this is not the case because it is the notion of bringing poetry into everyday life that is fundamental, not the notion of interactivity. The notion of bringing poetry into everyday life is quintessentially romantic. And in order to comprehend this idea we have to identify the most basic premises of romanticism which are: first, the creativity of the unconscious mind; and, second, the aesthetics of the sublime and its relationship with the noumenal. Theoretically anyone could create 
a readymade work of art in the manner of Marcel Duchamp. Anyone could create a cut and paste photomontage or an automatic painting. In practice, however, the only people who do this are fine artists. The reason why the techniques developed by Dada and Surrealism remain the preserve of fine artists is because they are located within a romantic or postromantic philosophy that is intrinsically antithetical to commonsense and practical-functionalism.

This prejudice is informed by the romantic concept of nature. Beginning with Rousseau romanticism asserts a binary opposition between nature and society in which the first term is characterised as joyful, anarchic and positive and the second as resentful, hierarchical and negative. ${ }^{3}$ In German romantic philosophy this distinction evolves into an antagonism towards the modern philosophy of utilitarianism. ${ }^{4}$ And in the postromantic thought of Friedrich Nietzsche utilitarianism is contrasted with the intoxication and frenzy (Rausch) of artistic creation that stems from the unbounded creativity of the unconscious ("active") mind conceived as a state of nature. ${ }^{5}$ The antagonism towards the rationalism of modern society evident in postromantic movements such as Dada and Surrealism, Situationism, and most recently "relational

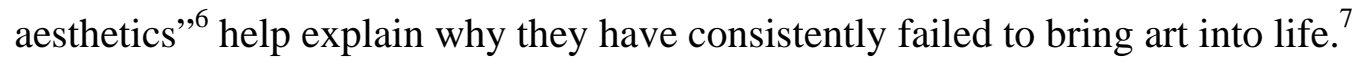

The convergence of art and design in De Stijl, Constructivism and the Bauhaus, in contrast, provided an avenue for bringing art into life in a manner that did not entail a romantic/postromantic antagonism towards rational functionalism. Such movements were able to create an elegant visual poetics capable of reconciling sublimity with functionality and reaching into everyday life via architecture and design. But in order to achieve this end their aesthetic framework intersected with the dominant discourse of technoscientific rationalism. In contrast Dada and Surrealism, the movements that found postmodern art, are radically antirationalist. Crucial to their aesthetics is the romantic premise that creativity is located in the unconscious mind conceived as a psychic state of nature.

We find ourselves therefore caught between a thesis and antithesis that awaits an effective synthesis. The thesis is the dominant social discourse of functionalism and the antithesis is the romantic/postromantic demand for a sublime poetics to be brought into everyday life. One way of overcoming this opposition is to examine those aspects of postromantic aesthetics that take the pathway of mythologising the creativity of nature via evolution. Following this route we uncover fundamental 
weaknesses in the postromantic position that can help in adumbrating a potential synthesis.

When we examine the response to Darwinian evolution in Nietzsche and Henri Bergson we discover a romanticist longing for the sacred that was lost when Christianity ceased to be a binding force in European society. For postromantic philosophy evolution offers an alternative source of the sacred in the form of the creative forces of nature. This is evident when evolution is figured by Nietzsche in terms of a mysterious "form shaping force"; ${ }^{8}$ by Bergson in terms of a "universal vital impulsion"; 9 and, most recently, in Gilles Deleuze and Félix Guattari’s evocation of an originary desiring intensity figured in their essentially occult notion of the "body without organs". 10

Bergson, however, is instructive when he critiques mechanistic rationalism in Creative Evolution ${ }^{11}$ arguing that science, mathematics and common sense can never grasp the interconnected flux of the noumenal thing-in-itself beyond the phenomenal limits of rational cognition. For Bergson science slices the dynamic interconnected flux of nature into static snapshots, closed systems, which can be analysed rationally. And in so doing it creates an artificial, mechanistic picture of nature: a manifold series of still photograph-like images that Bergson claims cannot be reconnected to give a proper, organic, account of living reality. Yet what is remarkable is that Bergson informs us that this way of addressing reality was created by evolution itself: "the intellectual tendencies innate to-day, which life must have created in the course of its evolution, are not at all meant to supply us with an explanation of life: they have something else to do"12 and that something else is to survive in the practical world. In this sense Bergson accepts the Darwinian premise that evolution operates on the basis of practical functionality epitomised in the process of natural selection. But surely there is a contradiction here because according to Bergson evolution is creative. Can we not, therefore, posit an interconnection between reason, practical application and creativity?

One can certainly argue that Bergson's admission that rational consciousness is a product of evolution reveals that his critique of science is flawed because it is in fact possible to deconstruct specific natural phenomena and reconstruct them in a manner that is fully functional. ${ }^{13}$ The discovery of the genetic code, after Bergson, has emphasised that nature is essentially componential and combinatorial as well as being dynamic and interconnected. ${ }^{14}$ 
Bergson's antagonism towards the practical-functional orientation of rational consciousness needs to be situated in its fin de siècle historical context in which postromantic thinkers were reacting against what they saw as the despiritualisation of society by mechanisation and utilitarianism. Bergson’s fundamental answer to this state of affairs is to postulate an expanded state of consciousness, akin to mystical experience, which is the intuition of duration, wherein one experiences the flux and multiplicity of phenomena thereby catching a glimpse of an interconnected dynamic totality. But in order to do this Bergson informs us that the "mind has to do violence to itself”, 15 a notion that recalls Arthur Rimbaud's recipe for creativity as a "long, immense and deliberate derangement of all the senses". ${ }^{16}$

In Deleuze and Guattari's Capitalism and Schizophrenia ${ }^{17}$ the idea of altered consciousness is even more overt, being modelled on schizophrenia whether natural, or artificially induced via psychotropic chemicals. ${ }^{18}$ And their notion of the "body without organs" (BwO) which they characterise as the "cosmic egg"19 of life is appropriated from the schizophrenic surrealist Antonin Artaud. Deleuze and Guattari's BwO is blatently mystical, figured as a singularity of desiring intensity that transcends the dimensions of space, ${ }^{20}$ an impossibility in scientific terms unless we think of it in terms of the singularity that initiated the Big Bang, and even then it becomes an essentially mystical account of creation.

But what is valuable in Capitalism and Schizophrenia is Deleuze and Guattari's recourse to chaos theory and their concept of the "machinic”. Unlike Nietzsche or Bergson they accept that the creativity of evolution should be understood in terms of the production of machines. The first volume of Capitalism and Schizophrenia, Anti-Oedipus, begins "Everywhere it is machines-real ones, not figurative ones: machines driving other machines, machines being driven by other machines, with all the necessary couplings and connections”. ${ }^{21}$ Machinic machines, however, are not ordinary machines, they are impelled by desire, by something akin to Bergson’s universal vital impulsion. ${ }^{22}$

The romantic/postromantic focus on a sacred desiring force at the core of nature is an anthropocentric, mythopoetic construction that has no basis in science not even in the most counter-mechanistic science of complexity theory. Although Deleuze and Guattari appropriate chaos theory they do so in order to assimilate it into a poetic construction that is fundamentally informed by a romanticist inclination to figure 
nature as sacred where the sacred is characterised in terms of desire, a cosmic striving for life diametrically opposed to the coldness of rationalistic functionalism. ${ }^{23}$

Complexity theory, in contrast, does not entail an anthropocentric projection of human desire into a sacred cosmic principle. Instead complexity theory can be understood as a process philosophy that has no need to posit a mysterious force of nature because the mystery is located within complex interconnected interactions between a manifold of components, what one might refer to as the cosmic combinatoire that arises out of what Christopher Langton has called the "edge of chaos”. ${ }^{24}$

The mystery of the evolution of life lies in the combinatoriality of molecules which in turn arise out of the combinatoriality of subatomic particles that allow the creation of atoms. In particular we can think of the curious lengths that molecular evolution had to go to in order to produce the building blocks of life that are proteins. Proteins are complex enfolded polymeric chains composed of amino acid sequences. A manifold of proteins with a vast variety of physical characteristics and biochemical functions can be produced from a repertoire of only twenty amino acids. But to produce the protein combinatoire evolution had to invent the genetic code through a process Christian de Duve describes as “molecular selection”. 25

Even though nature does not have foresight it is indeed a remarkable coincidence that when chains of nucleobases such as adenine, guanine, uracil, and cytosine link together they can create a template for the production of the most structurally complex molecules that are proteins. There may be no foresight, no question of actually designing the biomolecular building blocks of life, but it does appear that we are dealing with a remarkably serendipitous combinatoire wherein chance interactions between prebiotic molecules are accompanied by the promise of remarkable functional structures: first, proteins; second, single-celled organisms; third, multicellular organisms; and fourth, nervous systems and brains.

Deleuze and Guattari use the term "double articulation” to describe the relationship between nucleobases and the amino acids that constitute proteins. ${ }^{26}$ Double articulation is a term taken from semiotics which refers to the combinatorial nature of language wherein a finite set of sounds and syntactic rules can produce a manifold of combinations. ${ }^{27}$ But double articulation proliferates: language is composed not only of the syntagmatic dimension of phonemes and syntactic rules but also the paradigmatic dimension of metaphor and so we might speak of a second 
doubling. Then we can add the dimension of speech acts which leads to third doubling. In addition there is the process of usage wherein language evolves "molecularly" as sounds alter, new words are formed and syntactic rules transform via mutation. The more we examine language the more levels of articulation appear: expanding into fractal doublings-of-doublings en abyme that evoke Feigenbaum's famous diagram of period doubling; ${ }^{28}$ culture and nature intersect.

Why and how molecular components can interconnect to create increasingly complex machines is currently inexplicable even by the mysterious emergence of attractors that enable self-organised criticality because extraordinary serendipity also plays a role. ${ }^{29}$ But despite such mystery to have recourse to a romantic anthropocentric thesis that life emerged out of a cosmic desiring impulse seems radically unnecessary.

Evolution provides a model for the achievement of a synthesis between the practical demands of society and the postromantic demand for a poetics of the sublime. Evolution understood in terms of complexity theory is redolent with sublimity. But despite the fact that complexity theory is counter-mechanistic it does not replace the venerable scientific methodology of analytical reductionism; instead it complements it. Moreover, complexity theory is not concerned with sacralising the sublimity of nature in the manner of romantic and postromantic aesthetics. Accordingly it offers aesthetics a desacralised notion of the sublime.

A complexity theoretical framework allows a reconciliation of the sublimity of evolution with the practical-functional. We can return to Bergson's admission that rational analysis is the product of evolution. ${ }^{30}$ Evolutionary process is sublime but it is also practical-functional. As Deleuze and Guattari admit, evolution leads to the production of machines; but we do not have to follow their sacralisation of the machinic via the anthropocentric projection of human desire onto cosmic process.

The chain of chance, self-organisation and natural selection that created amino acids, nucleobases, genetic code, proteins, single-celled then multicellular organisms and minds is sublime. But such sublimity does not entirely confound scientific rational analysis. ${ }^{31}$ Instead rational analysis, which entails rational agency and the capacity to intuitively and imaginatively play with ideas, can be understood as a component of the multidimensional space of the cosmic combinatoire, ${ }^{32}$ which can be related to what Deleuze and Guattari refer to as the "plane of immanence". 33 
Moreover, the acknowledgement that evolution leads to the production of practical-functional machines allows us to interlink natural evolution with cultural evolution, what Georg Lukács referred to as "second nature", which appears to be an additional dimension of evolution. In a manner that resonates with the discourse of romanticism/postromanticism Lukács equated second nature with reification. ${ }^{34}$ But from an evolutionary perspective society considered as second nature need no longer fit into the romanticist binary opposition between nature as positive and society as negative if both nature and society can become considered as part of an interconnected combinatoire in a multidimensional phase space, akin to the "plane of immanence", that offers the potential of a multiplicity of plateaus of machinic production. $^{35}$

With some critical modifications Deleuze and Guattari's concept of the machinic opens up the possibility of reconciling the thesis that is the dominant social discourse of functionalism with the antithesis that is the postromantic ambition to bring a poetics of the sublime into everyday life. The critical modification is to dispense with the romantic/postromantic anthropocentric projection of human desire onto nature. From a complexity theoretical standpoint suggesting that desire is a force of evolution seems both anthropocentric and anachronistic. Certainly, human desire is the product of the body-brain which is a product of evolution. But that does not entail that desire exists beyond the body-brain in the form of a Bergsonian universal impulsion. It is possible to reconfigure Deleuze and Guattari's valuable concept of the machinic by retaining their notion of the sublimity of the machinic without figuring this sublimity in terms of a universal desiring impulsion such as the body without organs. This leads us away from hyperbolic metaphysical speculation towards a rapprochement between the machinic sublimity inherent in the functional orientation of natural evolution and its recapitulation in second nature.

An evolutionary aesthetics that relinquishes the romantic/postromantic prejudice against the practical-functional is in a position to re-establish the historic liaison between art and design. The question that can be posed at the end of this discussion is whether we can imagine an evolutionary aesthetics informed by scientific fields such as complexity theory and connectionism that preserves a sense of the sublime without denigrating practicality? A reconfigured version of Deleuze and Guattari's machinic aesthetics that reconciles sublimity with functionality might be as 
successful in bringing art into life as was the machine aesthetic in the first half of the twentieth century. 


\section{NOTES}

${ }^{1}$ Peter Bürger, Theory of the Avant-Garde, trans., M. Shaw (Minneapolis: University of Minnesota Press, 1984). Originally published in Germany in 1974.

${ }^{2}$ Ibid., 53.

${ }^{3}$ The use of the term “resentful” here refers both to Rousseau's notion of amour-propre (pride) and Nietzsche’s notion of ressentiment.

${ }^{4}$ Frederick C. Beiser notes "Novalis, Friedrich Schlegel, and Schleiermacher all lamented the utilitarianism of modern culture, its tendency to value things only as a means to physical happiness. What the bourgeois cannot consume does not exist for them. Naturally, this leaves no place for the higher values of life, philosophy, art, and religion. Even worse, it demeans social relationships, treating them as a means of achieving mutual benefit or advantage. The romantics employed a redolent word for someone who is devoted to the materialist ethic of modern society: the philistine (der Philister). The philistine will act only for the sake of comfort; he saw art as only a form of entertainment, and religion simply as an opiate he could turn to in distress. He would transform all of his life into a repetitive routine and conform to the moral, religious, and political status quo as long as it satisfies the craving for comfort and security. The purpose of life for the philistine is simply to exist and propagate. The romantics saw philistinism as the inevitable result of the modern economy. The increasing division of labor, the constant quest for profit, and the development of technology not only satisfied basic needs but created new ones. Hence the treadmill of economic life had become self-perpetuating.” Frederick C. Beiser, Enlightenment, Revolution, and Romanticism: The Genesis of Modern German Political Thought, 1790-1800 (Cambridge, Mass: Harvard University Press, 1992), 234.

${ }^{5}$ Robert C. Solomon notes “Nietzsche’s (traditional) German disdain for utilitarianism and its philosophy of comfort" observing that, in contrast, for Nietzsche "we get pleasure from exercising and feeling our power. ... Nietzsche talks (with characteristic enthusiasm) about the Rausch (intoxication, frenzy) that he considers essential to art (or, rather, essential to inspired and great art)" Robert C. Solomon, Living with Nietzsche: What the Great "Immoralist" Has to Teach Us (Oxford; New York: Oxford University Press, 2003), 69. And with regard to Nietzsche's notion of the unconscious as "active", Nietzsche opposes the active unconscious to "reactive" consciousness. Robert John Ackermann notes that for Nietzsche "Consciousness is always a rigid and reactive force; this is why we have come to lose touch with our bodies, and both memory and habit have contributed to this alienation from self.” Robert John Ackermann, Nietzsche: A Frenzied Look (Amherst: University of Massachusetts Press, 1990), 148.

${ }^{6}$ Nicolas Bourriaud, Relational Aesthetics (Dijon: Les presses du reel, 2002).

${ }^{7}$ It is also not surprising that after Bürger's assertion that Dada and Surrealism initiate the turn away from the postromantic discourse of l'art pour l'art he concludes that the project was a failure because it was coopted by the fine art gallery system: "Once the signed bottle drier has been accepted as an object that deserves a place in a museum, the provocation no longer provokes; it turns into its opposite. If an artist today signs a stove pipe and exhibits it, that artist certainly does not denounce the art market but adapts to it. Such adaptation does not eradicate the idea of individual creativity, it affirms it ...” Bürger, Avant-Garde, 52. One can add that such cooption is the inevitable consequence of a separation of art and design.

${ }^{8}$ Keith Ansell-Pearson, The Transhuman Condition: A Report on Machines, Technics, and Evolution (London: Routledge, 1997), 92. Ansell-Pearson notes that the Nietzsche's concept of form-shaping forces was derived from Wihelm Roux, in particular Roux's 1881 text Der Kampf der Theile im Organismus (The Struggle of Parts in an Organism) which argued that natural selection was unable to account for Organbildung (the development of organs) since it relied on a purely external mechanistic influences as opposed to internal "vital" influences. Ibid., 98.

${ }^{9}$ Henri Bergson, Creative Evolution (New York: Henry Holt and Co, 1913), 50.

${ }^{10}$ Admittedly this summary of such philosophies is somewhat reductive. For example, although Nietzsche does not connect chance with evolution, the relationship between his concept of chance and his theory of the eternal return effectively characterises chance as something akin to a form shaping force. William Mackintire Salter observes that for Nietzsche there is order in chance due to the fact that the endless throws of the dice lead to "a semblance of succession or order ... in the world, despite its chance nature- or rather just because of this, for the recurrence is entirely a matter of accident and necessity, not the result of any design or ordering will.” William Mackintire. Salter, Nietzsche the Thinker: A Study (New York: Henry Holt, 1917), 161. Bergson, in contrast, rejects chance which is perhaps the weakest link in his theory of creative evolution. Deleuze and Guattari on the other hand resurrect Nietzsche's affirmation of chance and bring it in line with the advance of probabilistic mathematics in twentieth century science and this is especially evident in their references to chaos theory. See Gilles Deleuze and Félix Guattari, A Thousand Plateaus: Capitalism and Schizophrenia (Minneapolis: University of Minnesota Press, 1987), 486-487.

${ }^{11}$ Originally published in 1907

${ }^{12}$ Bergson, Creative Evolution, 21. 
${ }^{13}$ Take for example George Church's recent analysis and reconstruction of a functioning version of the "egg of life" that is the ribosome in an experiment carried out as part of Harvard University's Origin of Life Initiative. See http://www.technologyreview.com/biomedicine/22273/ accessed September 2009.

${ }^{14}$ With regard to the notion of interconnectedness, the other factor Bergson leaves out of the equation is chance which helps explain why it took approximately a billion years for the prebiotic primal soup to produce the genetic code and the first single-celled organisms, and a further 2.8 billion years for multicellular life to emerge.

Serendipitous, negentropic combinatoriality doesn't come easily in nature; which possibly explains why human conscious, cognitive agency evolved through natural selection.

${ }^{15}$ Henri Bergson, An Introduction to Metaphysics (Indianapolis: Hackett, 1999), 51.

${ }^{16}$ Laurence and Elizabeth Hanson, Verlaine: Fool of God (New York: Random House, 1957), 148. Interestingly

Stephen Thaler's computationally creative neural networks do something remarkably similar. See: http://www.imagination-engines.com/thaler.htm and http://www.mindfully.org/Technology/2004/CreativityMachine-Thaler24jan04.htm\%20 accessed September 2009.

${ }^{17}$ Capitalism and Schizophrenia consists of two volumes: Gilles Deleuze and Félix Guattari, Anti-Oedipus: Capitalism and Schizophrenia (London: Athlone, 1984); and Gilles Deleuze and Félix Guattari, A Thousand Plateaus: Capitalism and Schizophrenia (Minneapolis: University of Minnesota Press, 1987).

${ }^{18}$ Deleuze and Guattari refer to "the drugged body, the experimental schizo" Deleuze and Guattari, Thousand Plateaus, 150. They also cite the writings of Carlos Castaneda so popular during the LSD drug culture of the 1960s and early 1970s. Ibid., 161, 227.

${ }^{19}$ Ibid., 164.

20 “The BwO causes intensities to pass; it produces and distributes them in a spatium that is itself intensive, lacking extension. It is not space, nor is it in space” ibid., 153.

${ }^{21}$ Deleuze and Guattari, Anti-Oedipus, 1.

${ }^{22}$ Such machinic mechanisms of desire are inspired by aesthetic sources including Michel Carrouges identification of “'celibate machines': Marcel Duchamp's painting 'La mariée mise à nu par ses célibataires, même' ('The Bride Stripped Bare by Her Bachelors, Even'), the machine in Kafka's 'In the Penal Colony,' Raymond Roussel's machines, those of Jarry's Surmâle (Supermale), certain of Edgar Allan Poe's machines, Villiers's Eve future (The Future Eve), etc.” Ibid., 18.

${ }^{23}$ Guattari provides one of the most succinct expressions of the postromantic concept of desire when he states: "Surely reason is to be found, first and foremost, at the core of the maddest desire! Desire is not necessarily disruptive and anarchic. Desire, once freed from the control of authority, can be seen as a more real and more realistic, a better organiser and more skilful engineer, then the raving rationalism of the planners and administrators of the present system. Science, innovation, creation - these things proliferate from desire, not from these pseudo-rationalism of the technocrats.” Félix Guattari, Molecular Revolution: Psychiatry and Politics. (Harmondsworth: Penguin [A Peregrine book], 1984), 86.

${ }^{24}$ Stuart Kauffman describes the edge of chaos using the phases of $\mathrm{H}_{2} \mathrm{O}$ as a metaphor: the edge of chaos is figured as the liquid territory capable of complex patterns of turbulence that exists in between the fixity of ice and the chaos of gas. See Elizabeth McMillan, Complexity, Organizations and Change (New York: Routledge), 22.

${ }^{25}$ Discussing the RNA World hypothesis of the origin of life de Duve explains: "It seems very unlikely that protometabolism produced just the four bases found in RNA, A [adenine], U [uracil], G [guanine] and C [cytosine], ready by some remarkable coincidence to engage in pairing and allow replication. Chemistry does not have this kind of foresight. In all likelihood, the four bases arose together with a number of other substances.... According to the present inventory, such substances could have included other members of the purine family (which includes A [adenine] and $\mathrm{G}$ [guanine]), pyrimidines (which include $\mathrm{U}$ [uracil], $\mathrm{T}$ [thymine] and $\mathrm{C}$ [cytosine]), nicotinamide and flavin, both of which actually engage in nucleotide-like combinations, and pterines, among other compounds. The first nucleic acid-like molecules probably contained an assortment of these compounds. Molecules rich in A, U, G and C then were progressively selected and amplified, once some rudimentary template-dependent synthetic mechanism allowing base pairing arose. RNA, as it exists today, may thus have been the first product of molecular selection." Christian de Duve, "The Beginnings of Life on Earth", originally published in the September-October 1995 issue of American Scientist. Online version accessed September 2009: http://www.americanscientist.org/issues/feature/the-beginnings-of-life-on-earth/4

26 "the genetic code ... is ... inseparable from ... a double articulation, this time between two types of independent molecules: the sequence of protein units and the sequence of nucleic units” Deleuze and Guattari, Thousand Plateaus, 42.

${ }^{27}$ Daniel Chandler notes that "Double articulation is seen as being largely responsible for the creative economy of language.” Online resource accessed September 2009: http://www.aber.ac.uk/media/Documents/S4B/sem08a.html

${ }^{28}$ Brian Massumi's interpretive and elaborative account of Deleuze and Guattari's theory, A User's Guide to Capitalism and Schizophrenia, notes that fractal geometry confounds the traditional logic of dualism. 
According to Massumi, confronted with fractal attractors dualisms fractally bifurcate "into countless new dualities proliferating in every direction” Brian Massumi, A User's Guide to Capitalism and Schizophrenia: Deviations from Deleuze and Guattari (Cambridge Mass: MIT Press, 1992), 15. Massumi also describes the fractal as "a web of proliferating fissures in an infinite regress towards the void" ibid., 22.

${ }^{29}$ For example, the Miller-Urey experiment shows that electric sparks in an atmosphere of methane, ammonia and hydrogen can create the amino acid components that make up the most structurally complex molecules of life that are proteins. But the Miller-Urey experiment does not produce nucleic acids. This is problematic because proteins cannot be created until nucleic acids polymerise into RNA and RNA complexifies into the protein producing mechanism that is the ribosome, the veritable egg of life. The extraordinary role of chance in the evolution of life is evident in current research which indicates that the nucleobase components of RNA and DNA arrived from space via meteorites; see Adam Rutherford, The Cell, (London: BBC Four, 2009), Part 3: "The Spark of Life”, broadcast 26 August. Even allowing for this extraordinary serendipity the question of how nucleobases linked up to form RNA and how RNA formed the egg of life that is the RNA-ribosome remains a mystery. No experiment has been able to produce RNA in the manner of the Miller-Urey experiment let alone the complex RNA configuration that is the ribosome. All that has been achieved is George Church's post factum analysis of a bacterial ribosome into its fundamental components followed by a successful reconstruction of functioning ribosomes in a test tube (see note 13 above). In spite of our detailed analytical knowledge of amino acid and nucleic acid chemistry the origin of life 3.5 billion years ago remains a sublime mystery.

30 "the intellectual tendencies innate to-day, which life must have created in the course of its evolution, are not at all meant to supply us with an explanation of life: they have something else to do” Bergson, Creative Evolution, 21.

${ }^{31}$ It seems inevitable that the groundbreaking Miller-Urey experiment will be followed up with another experiment that will reveal how RNA was formed and how the RNA-ribosome protein producing factory that is the egg of life came into being. It is highly unlikely that there is any need to posit a "cosmic egg" composed entirely of desiring intensity that lies outside of the dimensions of space as is the case in Deleuze and Guattari's concept of the body without organs in Capitalism and Schizophrenia (see note 20 above).

${ }^{32}$ One thinks here of Hilbert space: a multidimensional vector space.

${ }^{33}$ Deleuze and Guattari, Thousand Plateaus, 254-255. Keith Ansell-Pearson notes that the plane of immanence which is also a "plane of consistency" is a "flat multidimensional surface". Keith Ansell-Pearson, Germinal life: the Difference and Repetition of Deleuze (London: Routledge, 1999), 160.

${ }^{34}$ Keith Tester, The Inhuman Condition (New York: Routledge, 1995), 31.

${ }^{35}$ The title of Deleuze and Guattari's book A Thousand Plateaus is modest, because from a complexity theoretical point of view there could well be an infinity of plateaus. 